\title{
Quality of Extension Services: A Case Study of Farmers in Amathole
}

\author{
Isaac Azikiwe Agholor ${ }^{1}$, Nomahkaya Monde ${ }^{1}$, Ajuruchukwu Obi ${ }^{1} \&$ Odeyemi Akinwumi Sunday ${ }^{2}$ \\ ${ }^{1}$ Department of Agricultural Economics, Extension and Rural Development, University of fort Hare, South Africa \\ ${ }^{2}$ Department of Statistics, University of Fort Hare, South Africa \\ Correspondence: Isaac Azikiwe Agholor, Department of Agricultural Economics, Extension and Rural \\ development, University of fort Hare, South Africa. E-mail: isaaco477@yahoo.com
}

Received: November 10, 2012 Accepted: November 26, 2012 Online Published: January 15, 2013

doi:10.5539/jas.v5n2p204 URL: http://dx.doi.org/10.5539/jas.v5n2p204

\begin{abstract}
The trend in the contemporary society for accountability calls for the evaluation of extension services. Extension service providers should be saddled with the responsibility of ensuring that farmers are continually satisfied with services being delivered. In enhancing farmers' loyalty and confidence, extension feedback is becoming increasingly paramount. Customer satisfaction survey remains an essential tool for measuring the quality of services and outcome of programmes. The purpose of the study was to determine the quality related to innovation dissemination and teaching as perceived by farmers inthe adoption of new agricultural technologiesin Amathole District Municipality. Thespecific objectives of the study were to: describe how assessments of quality of Extension services differ by gender and the outcomes of the experiences with Extension services. Amathole district Municipality was used as the study population. The entire survey was carried out using a continuous sequence of contacts. A total of 900 useable surveys were pooled for the study. Farmers' gender was found to be linked with Extension service satisfaction and outcomes. However, females appear to have overall satisfaction with service delivery than males. The implication of this is that males are less likely to cultivate confidence and loyalty in extension services in Amathole district. Following these findings, concerted effort is required to improve extension services in the area by integrating more holistic participatory approaches to enhance equal involvement of male and female farmers in needs assessment, programme planning, designing, delivery and the full recognition of indigenous knowledge system.
\end{abstract}

Keywords: extension, customer satisfaction, quality, gender, services, dimensions

\section{Introduction}

The use of agricultural sector and extension education in reducing poverty in South Africa is important given the large resources available in the sector and the impressive agro-ecological diversity of the country. A major way to the development of agricultural production is the provision of quality extension services. The main potential to reduce rural poverty and inequality depends on the strong development of overall frameworks for the provision of social security, education and training, as well as health care, and in developing infrastructures in most rural areas (Organisation for Economic Co-operation and Development [OECD] 2006). For agricultural extension education in our community to be significant, then the farmers' environment must be explored, harnessed and identified with useful opportunities for quality extension education. During the post-apartheid period the Department of Agriculture was restructured which culminated to the establishment of new provincial Departments of Agriculture. However, the lapses identified in the home land era were also prevalent as the new Department of Agriculture were unable to still maintain support services to farmer. Some commercial farmers lost confidence in publicly provided extension services with the result that some of these farmers swapped to privately provided extension services (Vink \& Kirsten, 2003). In a report titled "The state of Extension and Advisory service within the Agricultural Public Service: A Need for Recovery" asserted that the readiness of all provinces in South Africa to deliver quality extension support services to farmers were already doubtful (Department of Agriculture, 2008). It is apparent that little is known about the capacity, quality of service, and performance of extension system in South Africa. Few studies have been conducted which placed emphasis on the quality of Extension services in areas related to quality teaching by Extension practioners in a developing country like South Africa. The National Education and Training Strategy for Agriculture and Rural Development (NETSARD) underlined some serious challenges which must be overcome to address the inability of extension staff in South Africa, these includes: the ratio of extension staff to commercial and subsistence farmers estimated as follows; commercial farmers 1:21, subsistence farmers 1:857 
and combined 1:878; distance between farmers, geographic areas covered by extension workers, client literacy, level of practical functioning of local farmers groups and associations (Department of Agriculture, 2005a). In a review of Extension services provided as part of the Farmers Support Programme (FSP) in South Africa (Harward and Botha, 1995), identified a range of problems: (i) Provision of poor quality Extension support to farmers in most cases. (ii) No reasonable contact between Extension and Research given that most research initiatives geared towards commercial farmers (iii) Extension methods were outdated and not suited to changing international Extension approaches (iv) farmers were encouraged to use farm inputs at too high a level against their performance achievement thus pushing many into debts.

Hackman and Wageman (1995) stated that "uncontrolled variance in process or outcomes is the primary cause of quality problems". Quality is the direct result of work processes within the organization and, in the area of Extension, it relates to aspect of programming and delivery of educational interventions. Clients or Customer Satisfaction Survey (CSS) are considered important assessment tool for measuring programme quality (Hatry, 1999; Ladewig, 1999; Rossi et al., 2007). When a client is very satisfied, it connotes that the organization offering the service is performing fine and thus enjoys very high level of loyalty (Terry \& Israel, 2004). The understanding of farmers experience with Extension measures another hidden dimension of programme quality. The major challenge facing Extension is meeting the ever changing needs of many farming population not only in South Africa but in other parts of the World. There is a need to provide agricultural extension workers with capacity, knowledge, and skills to assist communities to deal with challenges of increased agricultural production. However, to keep pace with these rural agriculture and development, the delivery of quality extension services become dependent upon two major elements: [i] relevant information and technology and [ii] quality teaching approach to bring about the desired change (Zainuddin \& Teh, 1982). It is important to assess the perception of farmers on the quality of extension support services in the study area.

\subsection{Theoretical Framework and Literature Review}

The perception of quality and satisfaction by farmers from extension performance rating has been diverse among researchers since 1980 (Allen \& Rao, 2000). Farmers who are regarded as customers in the delivery of extension programme desire quality benefits from the outcome of extension services. The extension officers are accountable for farmers' level of satisfaction, quality and relevance of educational learning programmes. Service quality focuses on evaluation that echoes the customer's perception of reliability, assurance, responsiveness, empathy and tangibility (Wilson, et al., 2008). According to Parasuraman et al. (1985), when service quality is perceived as high, then it will invariably lead to growth in customer satisfaction. However, various researchers' accepted the idea posited by Parasuraman et al. (1985) and they recognised that "Customer satisfaction is based upon the level of quality service that is provided by the service providers" (Saravana \& Rao, 2007, Lee et al., 2000). In a study by Kuo (2003) on service quality of community websites using Factor analysis, t-test, and Pearson correlation analysis for analysing the data collected from respondent in Taiwan; one of the results among others was that "on-line quality and information safety is positively related to the overall service quality, customer satisfaction, and loyalty". Other researchers like Wilson et al. (2008) revealed that the bases of customer satisfaction is a function of service quality, price, personal and situational factors. Several researchers' also examined the connection between total quality management and customer satisfaction as customer satisfaction is also based upon the level of quality service provided by an organisation (Lee et al., 2000). Theories linking customer satisfaction and quality of service have also been carried out by researchers. In his study, Wang and Hing-Po (2002) measured service quality in China's mobile phone market and stressed that there is an affiliation among service quality, customer value, customer satisfaction and on individual attitude. It is important to carry out a detailed analysis to examine whether the level of quality is the same across the diverse process carried on by an establishment (Royse et al., 2006). Meanwhile, some authors also surveyed the relationship between service quality, customer satisfaction, and store loyalty in the context of departmental store and establish that; "quality service impacts on attitude and satisfaction of customers of departmental stores." (Sivadas \& Baker-Prewitt, 2000). Customer Satisfaction Surveys (CCS) is an essential tool for measuring the quality of programmes offered (Lipsey \& Freeman, 2007). Positive clientele feedback portrays that an establishment is "on track" and may adore great levels of loyalty (Terry \& Israel, 2004). On the other hand, clientele feedbacks also assist in identifying if lapses exist in the delivery process adopted by extension practitioners. A good extension programme entails the setting out of definite objectives which is the basic for describing work process and for measuring conformity in implementation. Thus quality is perceived as a direct result of work processes occurring in an industry. In the environment of Extension, quality relates to programming and delivery of services with some dimensions. Numerous studies have shown, however, that gender issues, age and education (Oly Ndubisi, 2006; Anderson, Pearo, \& Wildener, 2008) have an influence on customer satisfaction and loyalty. In another study carried out by 
Mittal and Kamakura (2001); on service satisfaction of male and female auto-motor industry, found that female customers reported greater satisfaction with services offered than their male counterpart. Several other studies also posit that the ground for customer satisfaction varies between men and women (Anderson, Pearo and Wilderner 2008; Voss \& Cova, 2006). In summary, the values of Total Quality Management (TQM) and available study outcome on customer satisfaction and quality perception gives confidence to effort to assess and find out how well Extension is giving quality service to different farmers (male and female) in Amathole District Municipality.

\subsection{Purpose and Objectives}

The purpose of the study is to determine the quality related to innovation dissemination and teaching as perceived by farmers in the adoption of new agricultural technologies in Amathole District Municipality. The specific objectives of the study were: To describe how assessment of quality of Extension services differ by gender To describe the outcomes of the experiences with Extension services by gender.

\section{Materials and Method}

\subsection{Description of the Study Area}

Eastern Cape is located on the South-Eastern seaboard of South Africa. The Province of the Eastern Cape is the second largest of the nine provinces in terms of surface area, comprising $170600 \mathrm{~km}$ Square, which represents some $14.0 \%$ of the country's total land mass. The Province includes what was traditionally known as the Eastern Province, the Border and North-Eastern Cape area, as well as the former 'homelands' of Transkei and Ciskei. It borders the Indian Ocean in the South-East, the Free State Province and the Kingdom of Lesotho in the North, the Western and Northern Cape Provinces in the south west as well as KwaZulu-Natal Province in the North-East. The study was conducted in Amothole district which is one the seven districts of Eastern Cape Province of South Africa. The choice of this area for the study is because there is relative potential for livestock production and farmers. Amathole is surrounded by Chris Hani to the North, OR Tambo to the North-East, the Indian Ocean to the South-East, and Cacadu to the West. The seven district municipality in Eastern Cape are as follows: Alfred Nzo, Amatole, Cacadu, Chris Hani, Nelson Mandela Bay, OR Tambo, and Joe Gqabi (See Figure 1). The most recent official population estimates (Statistics South Africa, 2010) for the Eastern Cape give a figure of 6743 800, which is $13,5 \%$ of the national population of 49991300 in July 2010.The national population increased from 40, 6 million to 50 million, nearly a quarter, between 1996 and 2010. The annual population growth rate has however consistently fallen during this decade as the impact of HIV/AIDS takes its toll on South Africa. Consistently lower figures for the province in comparison to the country as a whole are probably due to the rural nature of much of the Eastern Cape. The provincial HIV/AIDS strategy reports the highest HIV prevalence in the province as being in the largest urban area, the Nelson Mandela Bay, and that 'lower HIV prevalence in rural areas is typically found throughout Africa but is less marked in South Africa' (Eastern Cape Aids Council, 2007). Amathole district comprises of the following eight Local Municipalities: Buffalo City, Mnquma, Mbhashe, Amahlathi, Nkonkobe, Ngqushwa, Great Kei and Nxuba.

Economic activities is concentrated in the Eastern Cape, with 72\% GDP generated in Nelson Mandela Bay Metro and Amatole district, which contain $42 \%$ of Provincial population. Manufacturing accounts for $88 \%$ of all provincial GDP in these two areas. The major crops grown in the area includes teff, barley, wheat, faba bean, sorghum, finger millet, maize, chickpea, and others. Different vegetables and fruits such as tomato, potato, onion, pepper, lettuce, carrot, garlic, and etc. grow in the area. Livestock reared in the area includes cattle, goats, sheep, and poultry.

\subsection{Sample and Sampling Procedure}

Samples of 450 male and 450 female farmers involved in crops and livestock production on subsistence, communal and commercial purposes were purposively selected for this study. Random sampling method was used which implies that no special sub-group of the population is particularly favoured in the sample selection. Purposive sampling was used to avoid gender, distance and roadside biases. The samples were taken from Amathole district which comprises of the following eight Local Municipalities: Buffalo City, Mnquma, Mbhashe, Amahlathi, Nkonkobe, Ngqushwa, Great Kei and Nxuba.

\subsection{The Approach}

In this study, quality is conceptualised in relation to services and not products. Service quality dimensions were used as a yardstick in the farmers' perspective to confirm if the Extension service sector provided quality services to farmers. Quality means different things to different people. Quality can be viewed as outstanding, as excellence, as aptness for purpose, as worth for money and as transformative. Most definitions of quality in extension education are clientele or farmers focused, that is meeting the customers' or farmers' anticipation. Quality 
extension covers areas like access to services, training and learning procedures and outcomes in a way that are influenced both by circumstance and by the variety of inputs available. The outcome of extension is assessed in the context of its stated and agreed objectives. However, the objectives and aims of extension services will frame the idea of quality which expresses relevance, accuracy, timeliness, and ease of understanding. Relevance (expressed as the rate at which services provided meets the demand of the farmers' situation); accuracy (expressed as the precision of information); timeliness (expressed as the urgency in responding to emergencies); and ease of understanding. The quantitative instrument was used for the data collection. Quantitative data are "the numbers" collected through surveys or other measurement techniques. The questionnaire survey was sent to a sample of farmers from the target population that had attended workshop, seminar, and farmers' day for the period 2009-2011. The entire survey was carried out using a continuous sequence of contacts. A total of 900 useable surveys were pooled for the analysis representing male: 160 for 2009, 158 for 2010, and 132 for 2011; female: 144 for 2009, 155 for 2010 and 151 for 2011. The 3-page questionnaire covers the following aspects: overall farmers' satisfaction on four dimensions of quality which includes: (relevance, accuracy, timeliness, and ease of understanding), outcomes of the use of extension services and demographic characteristics of farmers. The dimensions of service quality were: accuracy of information, timely delivery of information, relevance of information, and ease of use of information. These items were measured using a 5-point Likert scale. The outcomes of the use of extension services measured in the survey were: avenues to use information, whether the farmers' problem was solved or questions raised by farmers were answered, and sharing information with other farmers.

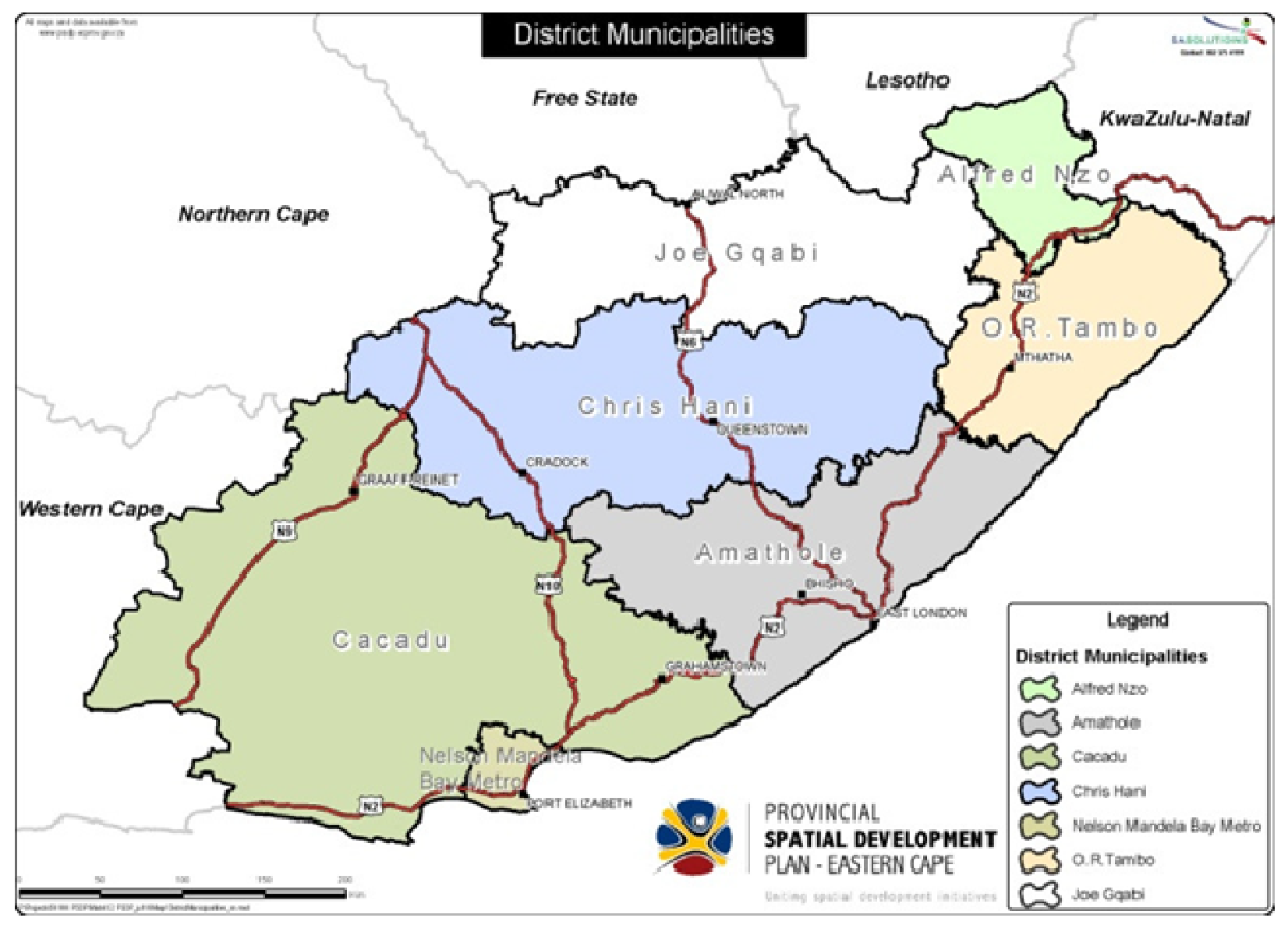

Figure 1. Map of Amathole district Municipality

Source: ECSECC, 2009. 


\subsection{Data Analysis Method}

The data obtained which were quantitative in nature were analyzed using different analytical techniques. Descriptive statistics involving frequency and percentage were used to analyse the data. The statistical significance of the variables in the descriptive part was tested using chi-square and SPSS.

\subsection{Reliability Analysis}

Reliability is the degree to which measures or data collection methods or analysis procedures are free from errors and will be able to yield consistent results (Saunders et al., 2009, Bryman \& Bell, 2003, Nunnally, 1978). In line with the classifications of Cronbach's alpha co-efficient by George and Mallery (2003), which indicates strong reliability if the alpha co-efficient exceeds 0.7 and moderate reliability if the alpha co-efficient exceeds 0.6 ; the reliability of the variables were tested. Table 1 shows the variables and Cronbach alpha. From the table, it is evident that the study meets the scales requirement by exceeding 0.7 which implies that there is strong internal consistency and reliability.

Table 1. Reliability Statistics for Scale

\begin{tabular}{lc}
\hline Variables: Quality service dimension & Cronbach's Alpha \\
\hline Timeliness of delivery & 0.912 \\
Accuracy of service & 0.814 \\
Relevance to situation & 0.821 \\
Ease of understanding & 0.823 \\
Opportunity to use/apply & 0.917 \\
\hline
\end{tabular}

\section{Results and Discussion}

Findings reveal that age group of between 21 years to 100years have more male than female farmers (table 2). Although age was not considered as a significant variable in determining quality in this study, however, male dominance in the agricultural sector is a common phenomenon in most community in the study area. This finding lends credence to Montshwe (2006), that the domination of males in farming is still common in communal areas of South Africa. Overall 32.67\% male and 30\% female respondent fall within the age range of 41-60years which shows that the older men and women are more into agricultural activities than youths in the area. The number of farmers (male and female) that had tertiary education was $20.67 \%$ and $19.33 \%$ respectively. Most of these farmers that had tertiary education were mostly commercial farmers. However, $14.67 \%$ of the male and $18 \%$ of the female had no formal school education but were also actively involved in farming. Farmers with primary education, junior secondary and secondary education were: primary education- male $17.33 \%$, female $13.33 \%$; junior school education- male $12.67 \%$, female $15.33 \%$; and secondary education- 34.67 and $34 \%$ respectively.

From the findings, important associations were discovered to exist between gender of the respondent and the perception of quality of extension services in the study area. A good percentage of women [18.14\%] were satisfied with timeliness of delivery of extension services as compared to [14\%] of men. Although the ease of understanding was not too different (table 6), more women were satisfied with the accuracy of service than men $(20 \%$ and $12 \%)$ respectively. In contrast, on the relevance to farmers needs/situation, more male $(30.00 \%)$ were dissatisfied as compared to $(25.56 \%)$ of female. Overall, the total number of female satisfied with extension services based on the scale of quality (very satisfied and satisfied) was higher than the male $(32.44 \%$ and $30 \%)$ respectively. On the contrary, the overall percentage of ease of understanding (scale = very satisfied and satisfied) between male and female were the same (72\%). Farm visits has a number of advantages which includes the familiarization of the extension agent with the farmer and his family; to give specific advice or information to the farmer and to arouse general interest among the farmers and stimulate their involvement in extension activities. Findings reveals that $26.67 \%$ of the female had contact with extension in their farms for the last twelve months while $24.67 \%$ of the male had contact with extension at the same period. However, visits at home were very rare with the female than the male (Table 2). Nevertheless, the frequency of visits by an extension officer to farmers may be connected to the availability of resources, staff and the nature of agricultural activity. In the study area farmers generally perceived that extension officers visit their projects less frequently. Subjective evidence from most of the respondents shows that extension officers visit farms less frequently than they should. As a standard practice, an extension officer should visit farmers at least once every week. There are no gender differences in contacts with extension for the 
last twelve months (table 5). Both male and female respondents had similar contact with extension ( $72 \%$ and $72.67 \%)$ respectively.

Table 2. Descriptive Statistics for Demographic Attributes Extension Experience for Farmers in the study area Demographics

\begin{tabular}{|c|c|c|c|c|c|}
\hline & & Male $(\mathrm{N}=450)$ & $\%$ & Female $(\mathrm{N}=450)$ & $\%$ \\
\hline \multicolumn{6}{|l|}{ Age: } \\
\hline & $21-40$ & 75 & 16.67 & 72 & 16.00 \\
\hline & $41-60$ & 147 & 32.67 & 135 & 30.00 \\
\hline & $61-80$ & 126 & 28.00 & 120 & 26.67 \\
\hline & $81-100$ & 72 & 16.00 & 63 & 14.00 \\
\hline & $100+$ & 42 & 9.33 & 48 & 10.67 \\
\hline \multicolumn{6}{|c|}{ Education: } \\
\hline & No school & 66 & 14.67 & 81 & 18.00 \\
\hline & Primary school & 78 & 17.33 & 60 & 13.33 \\
\hline & Junior secondary & 57 & 12.67 & 69 & 15.33 \\
\hline & Senior secondary & 156 & 34.67 & 153 & 34.00 \\
\hline & Tertiary & 93 & 20.67 & 87 & 19.33 \\
\hline \multicolumn{6}{|c|}{ Residence: } \\
\hline & Farm & 144 & 32.00 & 75 & 16.67 \\
\hline & Non-farm & 306 & 68.00 & 375 & 83.33 \\
\hline \multirow{4}{*}{\multicolumn{6}{|c|}{$\begin{array}{l}\text { Extension Experience } \\
\text { Extension contacts last } \\
12 \text { months } \\
\text { Types of Contact: }\end{array}$}} \\
\hline & & & & & \\
\hline & & & & & \\
\hline & & & & & \\
\hline & Farm/Office & 111 & 24.67 & 120 & 26.67 \\
\hline & Home visit & 12 & 2.67 & 6 & 1.33 \\
\hline & Farmers' day \& seminar/workshop & 327 & 72.67 & 324 & 72.00 \\
\hline
\end{tabular}

Table 3. Service Quality and Outcome by gender

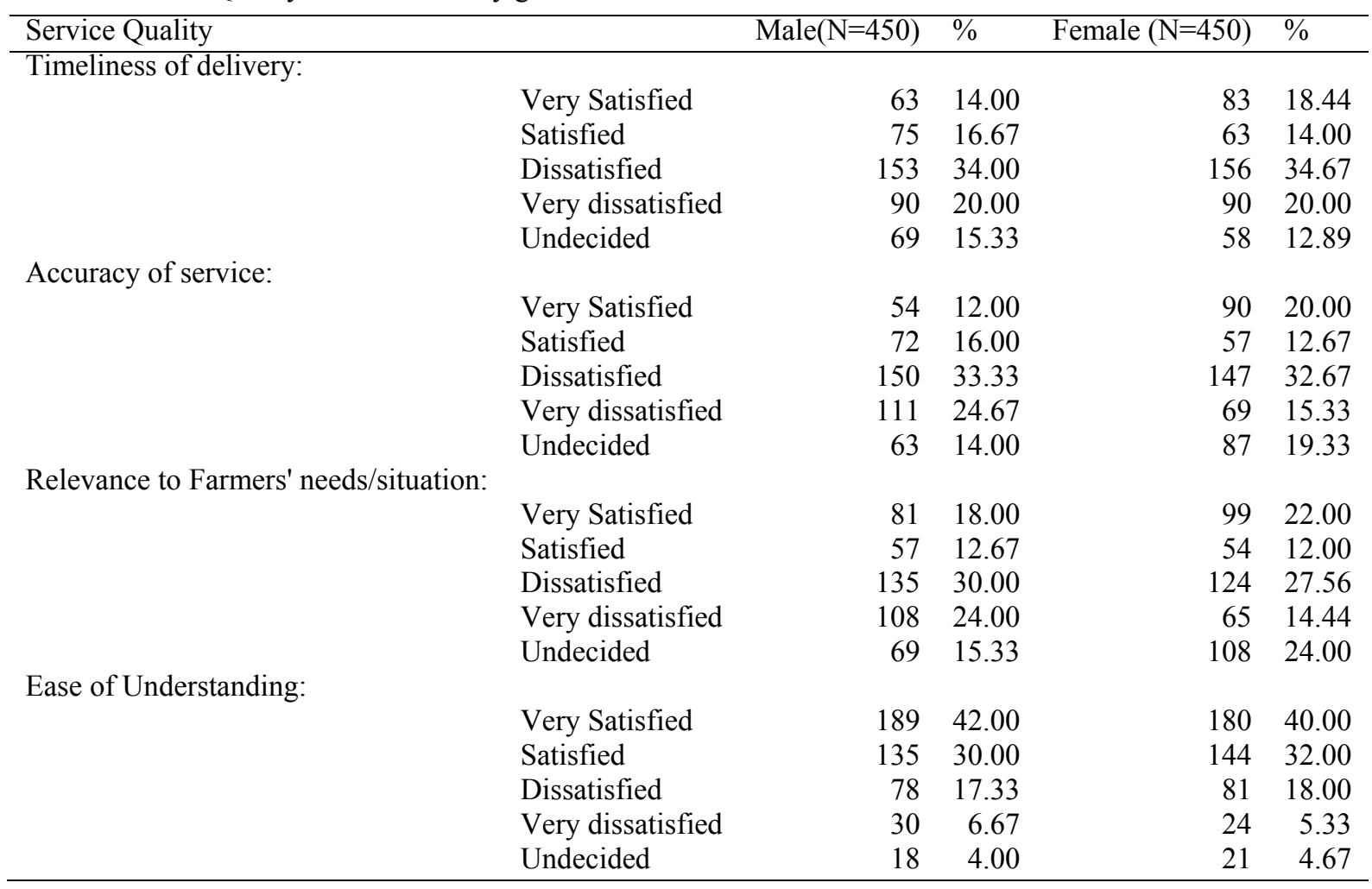


Table 4. Service Quality Outcome by Gender in the study area

\begin{tabular}{|c|c|c|c|c|}
\hline & & Male & Female & $p^{a}$ \\
\hline \multicolumn{5}{|l|}{ Service quality } \\
\hline \multicolumn{5}{|l|}{ Timeliness of delivery: } \\
\hline & Very Satisfied & 14.00 & 18.44 & \multirow{3}{*}{0.24} \\
\hline & Satisfied & 16.67 & 14.00 & \\
\hline & Other $^{\mathrm{b}}$ & 69.33 & 67.56 & \\
\hline \multicolumn{5}{|l|}{ Accuracy of service: } \\
\hline & Very Satisfied & 12.00 & 20.00 & \multirow{3}{*}{0.00} \\
\hline & Satisfied & 16.00 & 12.67 & \\
\hline & Other $^{\mathrm{b}}$ & 72.00 & 67.33 & \\
\hline \multicolumn{5}{|c|}{ Relevance to Farmers' needs/situation: } \\
\hline & Very Satisfied & 18.00 & 22.00 & \multirow{3}{*}{0.32} \\
\hline & Satisfied & 12.67 & 12.00 & \\
\hline & Other $^{b}$ & 69.33 & 66.00 & \\
\hline \multicolumn{5}{|l|}{ Ease of Understanding: } \\
\hline & Very Satisfied & 42.00 & 40.00 & \multirow{3}{*}{0.78} \\
\hline & Satisfied & 30.00 & 32.00 & \\
\hline & Other $^{\mathrm{b}}$ & 28.00 & 28.00 & \\
\hline \multicolumn{5}{|l|}{ Problem solved: } \\
\hline & Yes & 66.67 & 68.00 & \multirow{3}{*}{0.52} \\
\hline & No & 28.00 & 25.33 & \\
\hline & Undecided & 5.33 & 6.67 & \\
\hline \multicolumn{5}{|c|}{ Disseminate information to other farmers(sharing): } \\
\hline & Yes & 66.00 & 69.33 & \multirow{3}{*}{0.27} \\
\hline & No & 28.33 & 27.33 & \\
\hline & Undecided & 5.33 & 0.33 & \\
\hline \multicolumn{5}{|c|}{ Overall satisfaction with services: } \\
\hline & Very Satisfied & 60.00 & 65.33 & \multirow{3}{*}{0.22} \\
\hline & Satisfied & 13.33 & 10.67 & \\
\hline & Other $^{\mathrm{b}}$ & 26.67 & 24.00 & \\
\hline
\end{tabular}

${ }^{a}$-value is the significance level for test Chi-square ( for categorical variables).

${ }^{\mathrm{b}}$ Other includes Neither satisfied nor dissatisfied, Dissatisfied, and very dissatisfied.

From the table 4 depicting service quality outcome, $68 \%$ of the female reported that their problems were solved as against $66.67 \%$ of the male. However, $69.33 \%$ of females asserted that they were able to disseminate or share information to other farmers while $66 \%$ of the males shares information with other farmers. Overall, male also reported that they were less satisfied with each aspect of service quality (Timeliness of delivery, accuracy of service, relevance to farmers' needs/situation and ease of understanding) than females as shown in the table.

\subsection{Conclusions/Implications/Recommendations}

The study focused on the quality related to innovation dissemination and teaching as perceived by farmers in the adoption and use of new agricultural technologies in Amathole district Municipality. The specific objectives were to: (1) describe how assessments of quality of Extension services differ by gender. (2) describe the outcomes of the experiences with Extension services by gender. 
Gender of the respondents was discovered to be important variable and linked to quality of service delivery and outcome of extension services. Farmers reported high ratings of extension service delivery and gender perception was slightly different. However, females appear to have overall satisfaction with service delivery than males. This is particularly correct for timely delivery, relevance, accuracy and ease of understanding of information. This finding agrees with Davis (2006) that gender has an influence on perception about extension programme delivery.

The implication of this is that males are less likely to cultivate confidence and loyalty in extension services in Amathole district. This is a serious concern as our findings shows that more males are into farming as compared to the females. Following these findings, concerted effort is required to improve extension services in the area by integrating more holistic participatory approaches to enhance equal involvement of male and female farmers in needs assessment, programme planning, designing, delivery and the full recognition of indigenous knowledge system. Methods commonly used by extension officers to deliver extension programmes were seminars and conferences. Therefore, content and delivery methods should be carefully selected and varied so that the desired results and programme objectives are achieved. For effective instructions, farmers must be encouraged to form associations as this will assist in information dissemination. It is paramount to initiate a more uniform level of quality in Extension services for both male and female farmers in the area.

In summary, customer satisfaction survey is feasible and can assist in rating and evaluation of extension services administered, not only to the farmers in Amathole district but also to farmers in other countries. Extension must be held accountable for the relevance and impact of programmes delivered to the farmers (ECOP, 2005).

\section{References}

Allen, D. R., \& Rao, T. R. (2000). Analysis of Customer Satisfaction data: A comprehensive guide to multivariate statistical, loyalty and service quality research. Milwauke. ASQ Quality press.

Anderson, S., Pearo, L. K., \& Wildener, S. K. (2008). Drivers of services satisfaction: Linking customer satisfaction to the service concept and customer characteristics. Journal of service Research, 10(4), 350-370. http://dx.doi.org/10.1177/1094670508314575

Bryman, A., \& Bell, E. (2003). Business research method. New York: Oxford University Press.

Carmines, E.G., \& Zeller, R. A. (1979). Reliability and Validity Assessment. Beverly Hills, California: Sage publications. Census South Africa, 2001.

Davis, G. A. (2006). Learning style and personality type preferences of Community Development Extension Educators. Journal of Agricultural Education, 47(1), 90-97.

Department of Agriculture. (2005).

Department of Agriculture. (2008).

Extension Committee on Organisation and Policy's Leadership Advisory Council. (2005). 2005 Report. Washington, D.C., National Association of State universities and Land Grant Colleges.

Forum for Agricultural Research in Africa (FARA). (2007).

George, D., \& Mallery, P. (2003). SPSS for Windows step by step: A simple guide and Reference. 11.0 update (4th Ed.). Boston: Allyn \& Bacon.

Greene, J. C., Caracelli, V. J., \& Graham, W. F. (1989). Toward a conceptual framework for Mixed-method evaluation designs. Educational Evaluation and Policy Analysis, 11, 255-274.

Hackman., J. K., \& Wageman, R. (1995). Total Quality Management: Empirical and practical Issues. Administrative Sciences. Quality, 40(2), 309-342. http://dx.doi.org/10.2307/2393640

Hatry, H. P. (1999). Performance Measurement: Getting results. Washington: Urban institute Press.

Hayward, J. W., \& Botha, C. A. J. (1995). Extension, Training and Research. In Serving Small-Scale farmers: An evaluation of the OBSA's farmer support programmes.

Horton, D., Galleno, V., \& Mackay, R. (2003). Evaluation, Learning, and Change in Research and Development organizations. Discussion paper No. 03-2. The Hague: ISNAR.

Jick, T. D. (1979). Mixing qualitative and quantitative methods: Triangulation in action. Administrative Science Quarterly, 24, 602-611. http://dx.doi.org/10.2307/2392366

Kuo, Y. F., (2003). A study on Service Quality of virtual Community websites, Total Quality Management \& Business Excellence, 13(4), 460-471. 
Ladigewig, H. (1999). Accountability and the Cooperative Extension system. Paper presented at the Cooperative Extension programme and Leadership conference.

Lee, H., Lee, Y., \& Yoo., D. (2000). The Determinants of Perceived Service Quality and Its relationship with Satisfaction, Journal of Service Marketing, 14(3), 212-225. http://dx.doi.org/10.1108/08876040010327220

Lipsey, P. H., \& Freeman, H. E. (2004). Evaluation a Systematic Approach (7th ed.) Thousand Oaks, CA, Sage.

Mittal, V., \& Kamakura, W. A. (2001). Satisfaction, Repurchase intent and Repurchase Behaviour: Investigating the moderating effect of customer characteristics. Journal of marketing research, 38(1), 122-135. http://dx.doi.org/10.1509/jmkr.38.1.131.18832

Montshwe, D. B. (2006). Factors affecting participation in mainstream cattle markets by Small-scale cattle farmers in South Africa. MSc Thesis, University of Free State, RSA.

Morgan, G., \& Smircich, L. (1980). The Case for qualitative research. Academy of Management Review, 5, 491-500.

Nunnally, J. C. (1978). Psychometric Theory (2nd ed.). New York: McGraw Hill.

Oly Ndubusi, N. (2006). Effects of gender on customer loyalty: A Relationship Marketing Approach. Marketing Intelligence and planning, 24(1), 44-52.

Organisation for Economic Cooperation and Development (OECD). (2006). Review of Agricultural policies, South Africa: Highlights and policy recommendations. OECD Publications No. 83691.

Parasuraman, A., Zeithaml, V. A., \& Berry, L. L. (1985). A conceptual Model of Service Quality and its implications for future research. Journal of Marketing, 49, 43-49. http://dx.doi.org/10.2307/1251430

Rossi, P. H., Lipsey, M. W., Freeman., H. E. (2007). Evaluation: A Systematic Approach. (7th Ed.) (Preferred. 6th ed. Acceptable). Beverly Hills: Sage.

Royse., D. D., Thyer, B. A., Padgett, D. K., \& Logan. T. (2006). Programme Evaluation: An introduction (4th edn) Belmont C.A: Thomson books

Saravanan, R., \& Rao, K. S. P. (2007). Measurement of Service Quality from the Customer's perspective-An empirical study. Total Quality Management, 18(4), 435-449. http://dx.doi.org/10.1080/14783360701231872

Saunders, M., Lewis, P., \& Thornhill, A., (2009). Research Methods for business students 4th edition Pearson education limited.

Sivadas, E., \& Baker-Prewitt, J. L. (2000). An Examination of the Relationship Between Service quality, customer Satisfaction, and store Loyalty. Journal of Retail \& Distribution Management, 28(2), 71-88.

Terry., B. D., \& Israel, G. D. (2004). Agent performance and Customer Satisfaction. Journal of Extension, 42(6). Retrieved from http://www.joe.org/joe/2004/december/a4.shtml

Vink, N., \& Kirsten, J. (2003). Agriculture in the National Economy. In L. Niewoudt, \& J. Groenewald (Eds.), The Challenge of Change: Agriculture, Land and the South African Economy. Pietermaritzburg: University of Natal Press.

Vink, N., \& Kirsten, J. (2003). Agriculture in the National Economy. In L. Niewoudt, \& J. Groenewald (Eds.), The challenge: Agriculture, land and South Africa Economy. Pietermaritzburg: University of Natal press.

Voss, Z. G., \& Cora, V. (2006). How sex differences in Perception Influences customer Satisfaction: A study of theater audience. Marketing theory, 6(2), 99-198. http://dx.doi.org/10.1177/1470593106063983

Wang, Y., \& Hing-Po, L. (2002). Service Quality, Customer Satisfaction and Behaviour Intentions. Evidence from China's telecommunication industry, 4(6), 49-57.

Wilson A., Zeithaml, V. A., Bitner, M. J., Gremler, D. D. (2008). Services Marketing. McGraw-Hill Education.

Yauch, C. A., \& Steudel, H. J. (2003). Organizational Research Methods.

Zainuddin, A. P., \& Teh, S. B. (1982). Approaches Towards Distict Development Models for Multi-agency team work: Training for Agriculture and Rural development. Rome: United Nations Food and Agriculture Organisation. 